\title{
SOME ENGINEERING PROPERTIES REQUIRED TO PRECISION SEEDING OF DIFFERENT RICE GENOTYPES
}

\author{
EL-KEWAY, A. A. ${ }^{1}$, M. I. ELMEADAWY ${ }^{1}$, W. H. M. EL-KALLAWY ${ }^{2}$, \\ A. G. M. HEFEINA ${ }^{2}$ and H. A. EL-SHERBINY ${ }^{2}$
}

1. Agric. Eng. Res. Inst. (AEnRI), Giza.

2. Field Crops Res. Inst. - Rice Res. Department.

(Manuscript received 12 August 2018)

\begin{abstract}
$\mathrm{K}$ nowledge on physical properties of rice grains is an important tool for designing agricultural machines and other equipment to handle planting, harvesting, processing, packaging and storing. The most common rice genotypes grown in Egypt is 19 rice genotypes (12 rice cultivars and 7 promising lines) but the data on its physical properties is still lacking. The aim of this study is to investigate some engineering properties of 19 rice genotypes which grown in Egypt and setup database for rice genotypes as well as its use to design Precision agriculture machines at different seed moisture contents for various manner of direct seeded rice approaches. Laboratory experiments were

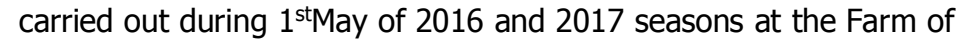
Rice Research Department, Field Crops Research Institute, Kafr ElSheikh Governorate collaborated with Tractor Farm Machinery Test and Research Station - Alex). The rice grains properties of (dry, soaked and incubated for 24 and 48 hours) were tested. The obtained results indicated that, the mean values of moisture contents for all rice genotypes were $(14.38 \%, 14.81 \%, 25.67 \%$, $26.02 \%, 28.98 \%$ and $29.37 \%$ ) for dry, soaked (1day) and incubated (2days) in 2016 and 2017 seasons, respectively. Also the grain dimensions gradually parallel increased with additional moisture content increased for all rice grains genotypes. From these results, it was clear that the shortest dimensions of rice grains recorded $(1.92 \pm 0.08 \mathrm{~mm})$ with dry seeds. Herein, it leads to design the hole diameter for seed plate less than $1.92 \mathrm{~mm}$ for precision machine. Therefore, the pertinent hole diameter for all rice grains genotypes was $1.5 \mathrm{~mm}$. The results obtained were used to establish a database of all rice cultivars in Egypt to use in the development of direct agriculture machines with a precision farming system and determine the optimum number of grains per unit area according to the technical recommendations for growing rice cultivars.
\end{abstract}

Keywords: Physical properties, varieties, dry, soaked, incubated.

\section{INTRODUCTION}

Rice is considered one of the most important cereal crops in Egypt after wheat. The cultivated area of rice crop was about 1.430 million feddans ( 1 hectare $=2.38$ fed.) in year of 2016 that produced about 5.434 million ton paddy rice (RRTC, 2016). 
The main objectives of the National Rice Research Institute program are to develop a new variety of economic high-yield under water shortage as well as salt affected soils.

The precision agriculture is very important for reducing production costs and allows for a one seed or more by category on specified distance for each class. Precision cultivation of crops that require precise control of plant density, spacing between and within the rows. The crops include in this category all horticultural crops, field crops, and for a minute cultivation of rice crop was necessary to set up a database of all natural and engineering properties of seeds of rice cultivars and promising lines which help for designing of precision agriculture machines.

Matouk et al., (2004) indicated that the bulk density at loose and vibrated fill conditions was found to be inversely proportional to grain moisture content for the studied varieties of wheat, corn and barley, while it was directly proportional to grain moisture content for rice varieties. Also he found that, the true density for rice varieties increased with the increasing of grain moisture content, while it was decreased for wheat, corn and barley varieties.

Ibrahim et al., (2008) studied some physical properties of rice seeds before and after soaking procedures. They found that, the values of shape index (SI), actual seeds density $(\rho)$ and mass of 1000 seeds were about $2.81,99.96 \mathrm{~g} / \mathrm{cm}^{3}$ and $33.03 \mathrm{~g}$ for dry rice grains (Giza 178) at $12.6 \%$ seed moisture content, and about 2, 48.13 $\mathrm{g} / \mathrm{c} \mathrm{m}^{3}$ and $78.47 \mathrm{~g}$ for hasting emergence rice seeds at $35.2 \%$ seed moisture content, respectively. While the mass of 1000 grains of Egyptian hybrid rice No.1 were 22, $89 \mathrm{~g}$ according to Abo-Yousef et al., (2011). Also, from demonstrated data, it can be seen that weight 1000 grains and grain real density take the same trend, whereas its values were significantly increasing with increasing moisture content.

Varnamkhasti et al., (2008) mentioned some engineering properties of Sazandegi and Sorkheh varieties which may be useful for designing mulch of the equipment used for rough rice processing. It is recommended that other engineering properties such as mechanical, thermal, and rheological properties which measured or calculated to provide a fairly comprehensive information on design parameters involved in rice processing. Also, it is recommended that the effect of grain moisture content on physical properties should be investigated.

Bashar et al., (2014) revealed that 1000 seed mass, basic dimensions, sphericity and bulk density were increased when the moisture content increased from (14.26 up to $22.50 \%$ ) Meanwhile porosity and true density were decreased when moisture content increased from (14.26 to $22.50 \%$ ). These data are highly essential for designing and development of dehulling machine, raising rice seedling singly in nursery tray and as well as transplanter to plant seedling singly. 
Abo-Habaga et al., (2014) studied the physical and engineering properties of hybrid rice 1 seeds in laboratory experiments including the moisture content of the seeds (dry - soaked - incubated), seed dimensions (length - width - thickness), shape index, seed density, weight of 1000 seeds, sphericity, arithmetic mean diameter, geometric mean diameter, repose angle, dynamic coefficient of friction and terminal velocity. The results obtained were used to develop and manufacture a precision vacuum planter unit suitable for planting hybrid rice1 seeds in two rows with $150 \mathrm{~mm}$ apart between and within rows. Therefore, the main objective of current study was to investigate some engineering properties of 19 rice genotypes (12 cultivars and 7 new promising lines) in Egypt, in order to setup the database for rice genotypes and its impact on Precision agriculture systems at different seed moisture contents for direct sowing (dry - soaked - incubated) rice seeds.

\section{MATERIALS AND METHODS}

Laboratory experiment was carried out in 2016 and 2017 summer season at Rice Research section - Sakha Station at Kafr El-Sheikh Governorate collaborated with Tractor and Farm Machinery Test and Research Station -Alex. The current investigation aimed to stady some engineering properities of rice seeds, grain moisture content (Mc), mean dimensions Length (L), Width (W) and Thickness (Th), shape index $(\mathrm{Si})$, bulk and true density $(\rho)$, weight of 1000 seeds (Wi), sphericity (Sp), arithmetic mean diameter $(\mathrm{Da})$, geometric mean diameter $(\mathrm{Dg})$ and germination ratio (\%). for some Egyption rice genotypes which included 12 rice cultivars as well as 7 promising rice lines under laboratory centitions as presented in Table (1) under three moisture conditions of rice seeds (dry- soaked- and incubated).

\section{Studied characters:}

\section{(1) Grain moisture content:}

Seed moisture content was determined using Grain Moisture Tester Model Kett KM No. 148 -C Japan accuracy of $0.5 \%$. Three samples 50 seeds each were taken to determine the seed moisture content for all varieties at dry, soaking and incubated.

\section{(2) Mass of 1000 grains:}

Means of mass of 1000 seeds from (dry, soaked and incubated) rice grains, samples of 1000 seeds were randomly selected. Each sample was weighted using an electronic balance with an accuracy of $0.01 \mathrm{~g}$. 
Table 1. Genotypes and pedgree of 12 cultivated rices and 7 newely promising rice lines.

\begin{tabular}{|c|c|c|c|c|c|}
\hline No & genotypes & Origin & Parentage & Salient feature & $\begin{array}{l}\text { Grains } \\
\text { shape }\end{array}$ \\
\hline 1 & Sakha 101 & Egyptian & Giza $176 \times$ Milayang79 & $\begin{array}{l}\text { Japonica type/late maturing } \\
\text { / high yielding. }\end{array}$ & Medium \\
\hline 2 & Sakha 102 & Egyptian & GZ4096×Giza177 & $\begin{array}{l}\text { Japonica type / very early } \\
\text { maturing / high yielding. }\end{array}$ & Medium \\
\hline 3 & Sakha 103 & Egyptian & (Giza 177×Suweon 349) & $\begin{array}{l}\text { Japonica type / very early } \\
\text { maturing / high yielding. }\end{array}$ & Medium \\
\hline 4 & Sakha 104 & Egyptian & GZ4096×Gz4100 & $\begin{array}{c}\text { Japonica type/moderately } \\
\text { maturing / high yielding. }\end{array}$ & Medium \\
\hline 5 & Sakha 105 & Egyptian & GZ5581×Gz4316 & $\begin{array}{l}\text { Japonica type / very early } \\
\text { maturing / high yielding. }\end{array}$ & Medium \\
\hline 6 & Sakha 106 & Egyptian & (Giza 177×Hexi 30) & $\begin{array}{c}\text { Japonica type/early } \\
\text { maturing-high yielding. }\end{array}$ & Medium \\
\hline 7 & Sakha 107 & Egyptian & Giza 177×BL1 & $\begin{array}{c}\text { Japonica type/ early } \\
\text { maturing / high yielding. }\end{array}$ & Medium \\
\hline 8 & Giza177 & Egyptian & Giza 171×Yamj No1 & $\begin{array}{l}\text { Japonica type / very early } \\
\text { maturing / high yielding. }\end{array}$ & Medium \\
\hline 9 & Giza178 & Egyptian & (Giza175×Milyang49) & $\begin{array}{c}\text { Indica/Japonica/moderately } \\
\text { maturing/high yielding. }\end{array}$ & Medium \\
\hline 10 & Giza179 & Egyptian & $\begin{array}{c}(\mathrm{Gz} 6296 \times \mathrm{Gz} 1368-\mathrm{S}-5- \\
4)\end{array}$ & $\begin{array}{l}\text { Indica/Japonica moderately } \\
\text { maturing - high yielding. }\end{array}$ & Medium \\
\hline 11 & Giza182 & Egyptian & $\begin{array}{c}\text { (Giza } 181 \times \text { IR39422) } \\
\times \text { × Giza } 181 \\
\end{array}$ & $\begin{array}{c}\text { Indica-moderately maturing- } \\
\text { moderately yielding. }\end{array}$ & Slender \\
\hline 12 & Hybrid rice1 & Egyptian & IR69625×Giza 178 & $\begin{array}{c}\text { Indica/Japonica moderately } \\
\text { maturing / high yielding. }\end{array}$ & Medium \\
\hline 13 & $\begin{array}{c}\text { GZ10355-9-1- } \\
1-3 \\
\end{array}$ & Egyptian & GZ7456×BY-Gc-30 & $\begin{array}{l}\text { Japonica type / very early } \\
\text { maturing / high yielding. }\end{array}$ & Medium \\
\hline 14 & $\begin{array}{c}\text { GZ10333-9-1- } \\
1-3 \\
\end{array}$ & Egyptian & SKC23822×Yan len4 & $\begin{array}{l}\text { Japonica type / very early } \\
\text { maturing / high yielding. }\end{array}$ & Medium \\
\hline 15 & $\begin{array}{c}\text { GZ10332-19-2- } \\
2-2 \\
\end{array}$ & Egyptian & SKC23822×IR73964 & $\begin{array}{l}\text { Japonica type / very early } \\
\text { maturing / high yielding. }\end{array}$ & Medium \\
\hline 16 & $\begin{array}{c}\text { GZ10305-24-1- } \\
2-3 \\
\end{array}$ & Egyptian & GZ7768×Milyang 95 & $\begin{array}{l}\text { Japonica type / very early } \\
\text { maturing / high yielding. }\end{array}$ & Medium \\
\hline 17 & $\begin{array}{c}\text { GZ10154-3-1- } \\
1-1 \\
\end{array}$ & Egyptian & GZ6522×Sakha 101 & $\begin{array}{l}\text { Japonica type / very early } \\
\text { maturing / high yielding. }\end{array}$ & Medium \\
\hline 18 & $\begin{array}{c}\text { GZ10305-2-1- } \\
3-1-1 \\
\end{array}$ & Egyptian & GZ7768×Milyang 95 & $\begin{array}{l}\text { Japonica type / very early } \\
\text { maturing / high yielding. }\end{array}$ & Medium \\
\hline 19 & $\begin{array}{c}\text { GZ10264-9-2- } \\
1-2 \\
\end{array}$ & Egyptian & Sakha $101 \times$ SR22746 & $\begin{array}{l}\text { Japonica type / very early } \\
\text { maturing / high yielding. }\end{array}$ & Medium \\
\hline
\end{tabular}

\section{(3) Shape index:}

One hundred grains were taken randomly at the same time to estimate shape index in terms of length $(L)$, width $(W)$, and thickness $(T)$ by using a digital caliper with a sensitivity of $0.01 \mathrm{~mm}$. The obtained data were used to calculate the shape index of each sample, according to Ismail (1988).

Shape index $(\mathrm{SI})=\frac{L}{\sqrt{W \cdot T}}$ 
At (SI) $>1.5$ the seed is considered oval and (SI) $<1.5$ the seed is considered spherical.

\section{(4) Geometric, arithmetic mean diameter and grain surface area:}

The geometric, arithmetic mean diameter and seed surface area of hybrid rice seeds are determined from the samples taken in the same time of determining the seed moisture content using the following equations according to Mohsenin, (1986):

$$
\begin{aligned}
& D_{g}=(L W T)^{1 / 3} \ldots \\
& D_{a}=\frac{L+W+T}{3} \\
& A_{s}=2 \Pi(L . W) \ldots
\end{aligned}
$$

Where:

$$
\begin{array}{ll}
D_{g}=\text { Geometric mean diameter }(\mathrm{mm}), & A_{s}=\text { Seed surface area }\left(\mathrm{mm}^{2}\right), \\
D_{a}=\text { Arithmetic mean diameter }(\mathrm{mm}), & \mathrm{L}=\text { Length of seed }(\mathrm{mm}), \\
W=\text { Width of seed }(\mathrm{mm}), \text { and } & T=\text { Thickness of seed }(\mathrm{mm}) .
\end{array}
$$

\section{(5) The degree of sphericity:}

The degree of sphericity $(\phi)$ were determined from the samples of linear dimensions of all rice seed varieties in the same time of determining the seed moisture content using the following equations according to (Mohsenin, 1986).

$$
\phi=\frac{(L W T)^{(1 / 3)}}{L} \times 100
$$

\section{(6) Grain true and bulk density:}

The true density $\left(\rho_{t}\right)$ was determined by the toluene displacement method.The grain bulk density was determined using the liquid displacement method by immersing a certain mass of grain in a certain benzene alcohol solution. The increase in the cylinder volume gave the absolute volume of rice grain. Ten samples were taken to determine the grain density for each grain treatment. The density of rice grains was determined by using the following equation: (Mohsenin, 1986).

$$
\rho_{s}=\frac{M}{V}
$$

Where:

$$
\begin{aligned}
& \rho_{s}=\text { grain bulk density }\left(\mathrm{g} / \mathrm{cm}^{3}\right), \\
& \mathrm{M}=\text { mass of grains }(\mathrm{g}), \text { and } \\
& \mathrm{V}=\text { volume of the grain }\left(\mathrm{cm}^{3}\right) .
\end{aligned}
$$




\section{RESULTS AND DISCUSSION}

\section{Grains moisture content:}

Fig. (1) Showed that the average values of grains moisture content for all rice verities at dry, soaked and incubated grains. The results indicated that the mean values of moisture content for all rice genotypes in 2016 and 2017 seasons were (14.38, 25.67 and 28.98\%) and 14.81, 26.02 and 29.37\%) respectively for dry, soaked for one day and incubated for two days seed respectively. These means that the seed treatment either soaking or incubating impelled water to penetrate the seed and increase grain moisture content.
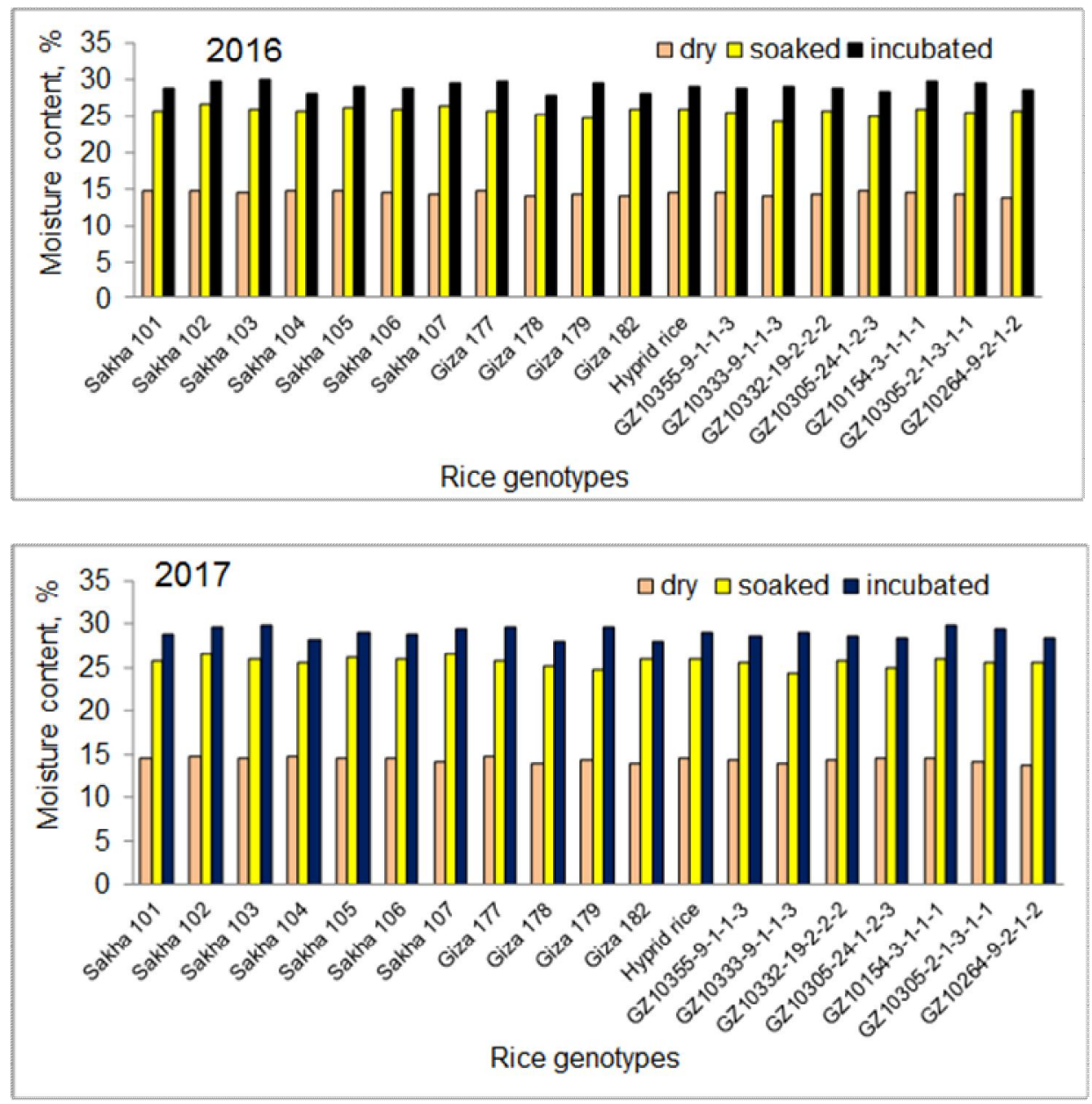

Fig. 1. Rice grain moisture content at different treatments when 2016 and 2017 seasons. 


\section{Effect of grain moisture content on grain dimensions:}

The average values of axial dimensions of rice grains dimensions (length, width and thickness) in 2016 and 2017 seasons at varying moisture content are shown in Table (2). It was noted that grain dimensions gradually increased with additional moisture content increased for all rice grains genotypes. From previous results, it was clear that the shortest dimensions of rice grains were at dry seeds, $(1.92 \pm 0.08 \mathrm{~mm})$ and so it was designed the hole diameter for seed plate less than $1.92 \mathrm{~mm}$ for precision machine. Therefore the pertinent hole diameter for all rice grains genotypes was $1.5 \mathrm{~mm}$.

\section{Effect of grains moisture content on bulk density of rice grains all rice genotypes:}

The effect of grains moisture content on bulk density of rice grains of all rice genotypes are shown in Figs ( 2 and 3 ). In general the bulk density increased with the increasing of grain moisture content for all rice genotypes. For old rice varieties, Giza178 recorded the highest values of bulk density, which increased from 535.24 to 546.27 to $574.22 \mathrm{~kg} / \mathrm{m}^{3}$ with increasing of grain moisture content from 14.38 to 25.67 to $28.98 \%$ for season 2016 and which increasing from 531.87 to 543.82 to 571.70 $\mathrm{kg} / \mathrm{m}^{3}$ with increasing of grain moisture content from 14.81 to 26.02 to $29.37 \%$ for season 2017 respectively. Meanwhile, Rice variety (Giza 177) recorded the lowest values of bulk density, which increased from 437.68 to 458.04 to $464.99 \mathrm{~kg} / \mathrm{m}^{3}$ with increasing from 14.38 to 25.67 to $28.98 \%$ for season 2016 and which increasing from 435.18 to 455.59 to $462.47 \mathrm{~kg} / \mathrm{m}^{3}$ with increasing of grain moisture content from 14.81 to 26.02 to $29.37 \%$, respectively.

Also, rice genotype (GZ 10332-19-2-2-2) recorded the highest values of bulk density, which increased from 453.24 to 532.55 to $555.64 \mathrm{~kg} / \mathrm{m}^{3}$ with increasing of grain moisture content from 14.38 to 25.67 to $28.98 \%$ for season 2016 and which increasing from 452.55 to 530.58 to $554.45 \mathrm{~kg} / \mathrm{m}^{3}$ for season 2017 , with increasing of grain moisture content from 14.81 to 26.02 to $29.37 \%$, respectively. Meanwhile, rice genotype (GZ10305-2-1-3-1-1) recorded the lowest values of bulk density, which increased from 442.64 to 473.48 to $479.98 \mathrm{~kg} / \mathrm{m}^{3}$ with increasing of grain moisture content from 14.38 to 25.67 to $28.98 \%$ for season 2016 , and which increasing from 441.51 to 471.51 to $478.79 \mathrm{~kg} / \mathrm{m}^{3}$ for season 2017 respectively for new rice genotypes respectively. From above results, it can be recorded that increasing the period of soaking seeds increased the average bulk density for all rice genotypes within the time period used in the study. 
Table 2. The average values of axial dimensions with standard deviation of all rice varieties in 2016 and 2017 seasons.

\begin{tabular}{|c|c|c|c|c|c|c|c|c|c|c|}
\hline \multirow{2}{*}{ Variety } & \multirow{2}{*}{$\begin{array}{l}\text { Moisture } \\
\text { content }\end{array}$} & \multicolumn{3}{|c|}{ Length (mm) } & \multicolumn{3}{|c|}{ Width (mm) } & \multicolumn{3}{|c|}{ Thickness(mm) } \\
\hline & & 2016 & 2017 & SD & 2016 & 2017 & SD & 2016 & 2017 & SD \\
\hline \multirow{3}{*}{ Sakha 101} & Dry & 7.74 & 7.80 & \pm 0.27 & 3.20 & 2.24 & \pm 0.13 & 2.08 & 2.10 & \pm 0.09 \\
\hline & Soaked & 7.87 & 7.93 & \pm 0.21 & 3.27 & 3.31 & \pm 0.13 & 2.28 & 2.30 & \pm 0.09 \\
\hline & Incubated & 7.88 & 7.94 & \pm 0.22 & 3.29 & 3.33 & \pm 0.14 & 2.31 & 2.33 & \pm 0.07 \\
\hline \multirow{3}{*}{ Sakha 102} & Dry & 7.71 & 7.77 & \pm 0.25 & 3.24 & 3.28 & \pm 0.12 & 2.12 & 2.14 & \pm 0.08 \\
\hline & Soaked & 7.81 & 7.78 & \pm 0.21 & 3.32 & 3.36 & \pm 0.11 & 2.34 & 2.36 & \pm 0.09 \\
\hline & Incubated & 7. 96 & 8.02 & \pm 0.23 & 3.35 & 3.39 & \pm 0.10 & 2.38 & 2.40 & \pm 0.08 \\
\hline \multirow{3}{*}{ Sakha 103} & Dry & 7.12 & 7.18 & \pm 0.23 & 3.19 & 3.23 & \pm 0.11 & 2.10 & 2.11 & \pm 0.09 \\
\hline & Soaked & 7.17 & 7.23 & \pm 0.23 & 3.26 & 3.30 & \pm 0.12 & 2.28 & 2.30 & \pm 0.08 \\
\hline & Incubated & 7.27 & 7.33 & \pm 0.22 & 3.27 & 3.31 & \pm 0.13 & 2.34 & 2.36 & \pm 0.09 \\
\hline \multirow{3}{*}{ Sakha 104} & Dry & 7.77 & 7.83 & \pm 0.22 & 3.18 & 3.22 & \pm 0.12 & 2.06 & 2.08 & \pm 0.09 \\
\hline & Soaked & 7.96 & 8.02 & \pm 0.20 & 3.37 & 3.41 & \pm 0.16 & 2.31 & 2.33 & \pm 0.07 \\
\hline & Incubated & 8.69 & 8.75 & \pm 0.22 & 3.43 & 3.47 & \pm 0.16 & 2.35 & 2.37 & \pm 0.09 \\
\hline \multirow{3}{*}{ Sakha 105} & Dry & 7.84 & 7.90 & \pm 0.25 & 3.17 & 3.21 & \pm 0.12 & 2.11 & 2.13 & \pm 0.09 \\
\hline & Soaked & 7.86 & 7.92 & \pm 0.26 & 3.18 & 3.22 & \pm 0.13 & 2.28 & 2.30 & \pm 0.07 \\
\hline & Incubated & 7.96 & 8.02 & \pm 0.24 & 3.21 & 3.25 & \pm 0.12 & 2.30 & 2.32 & \pm 0.10 \\
\hline \multirow{3}{*}{ Sakha 106} & Dry & 7.43 & 7.49 & \pm 0.21 & 3.16 & 3.20 & \pm 0.11 & 2.14 & 2.16 & \pm 0.09 \\
\hline & Soaked & 7.47 & 7.53 & \pm 0.22 & 3.22 & 3.26 & \pm 0.15 & 2.32 & 2.34 & \pm 0.08 \\
\hline & Incubated & 7.51 & 7.57 & \pm 0.23 & 3.32 & 3.36 & \pm 0.13 & 2.39 & 2.41 & \pm 0.08 \\
\hline \multirow{3}{*}{ Sakha 107} & Dry & 7.50 & 7.56 & \pm 0.28 & 3.35 & 3.39 & \pm 0.19 & 2.20 & 2.22 & \pm 0.08 \\
\hline & Soaked & 7.63 & 7.69 & \pm 0.30 & 3.37 & 3.41 & \pm 0.16 & 2.33 & 2.35 & \pm 0.08 \\
\hline & Incubated & 7.82 & 7.88 & \pm 0.34 & 3.39 & 3.43 & \pm 0.19 & 2.37 & 2.39 & \pm 0.10 \\
\hline \multirow{3}{*}{ Giza 177} & Dry & 7.44 & 7.50 & \pm 0.22 & 3.23 & 3.27 & \pm 0.13 & 2.17 & 2.19 & \pm 0.12 \\
\hline & Soaked & 7.48 & 7.54 & \pm 0.27 & 3.24 & 3.32 & \pm 0.13 & 2.32 & 2.34 & \pm 0.08 \\
\hline & Incubated & 7.53 & 7.59 & \pm 0.28 & 3.33 & 3.37 & \pm 0.15 & 2.41 & 2.43 & \pm 0.11 \\
\hline \multirow{3}{*}{ Giza 178} & Dry & 7.18 & 7.24 & \pm 0.23 & 2.82 & 2.80 & \pm 0.12 & 1.98 & 2.00 & \pm 0.09 \\
\hline & Soaked & 7.32 & 7.38 & \pm 0.24 & 2.86 & 2.90 & \pm 0.13 & 2.15 & 2.17 & \pm 0.09 \\
\hline & Incubated & 7.35 & 7.41 & \pm 0.37 & 2.88 & 2.92 & \pm 0.10 & 2.29 & 2.31 & \pm 0.07 \\
\hline & Dry & 7.24 & 7.30 & \pm 0.22 & 2.88 & 2.92 & \pm 0.11 & 2.07 & 2.09 & \pm 0.09 \\
\hline Giza 179 & Soaked & 8.03 & 8.09 & \pm 0.23 & 3.03 & 3.07 & \pm 0.12 & 2.13 & 2.15 & \pm 0.07 \\
\hline & Incubated & 8.18 & 8.24 & \pm 0.31 & 3.16 & 3.20 & \pm 0.13 & 2.23 & 2.25 & \pm 0.07 \\
\hline & Dry & 9.41 & 9.47 & \pm 0.31 & 2.56 & 2.60 & \pm 0.13 & 1.92 & 1.94 & \pm 0.08 \\
\hline Giza 182 & Soaked & 9.44 & 9.50 & \pm 0.44 & 2.62 & 2.66 & \pm 0.12 & 2.09 & 2.11 & \pm 0.08 \\
\hline & Incubated & 9.64 & 9.70 & \pm 0.39 & 2.69 & 2.73 & \pm 0.12 & 2.11 & 2.13 & \pm 0.08 \\
\hline & Dry & 8.05 & 8.11 & \pm 0.26 & 2.89 & 2.93 & \pm 0.11 & 1.96 & 1.98 & \pm 0.07 \\
\hline Hybrid rice 1 & Soaked & 8.05 & 8.11 & \pm 0.26 & 2.93 & 2.97 & \pm 0.10 & 2.09 & 2.11 & \pm 0.07 \\
\hline & Incubated & 8.18 & 8.24 & \pm 0.27 & 2.97 & 3.01 & \pm 0.12 & 2.19 & 2.21 & \pm 0.06 \\
\hline & Dry & 7.56 & 7.62 & \pm 0.26 & 3.32 & 3.36 & \pm 0.18 & 2.16 & 2.18 & \pm 0.11 \\
\hline GZ10355-9-1-1-3 & Soaked & 7.88 & 7.94 & \pm 0.31 & 3.40 & 3.44 & \pm 0.18 & 2.21 & 2.23 & \pm 0.07 \\
\hline & Incubated & 8.03 & 8.09 & \pm 0.29 & 3.51 & 3.55 & \pm 0.18 & 2.31 & 2.33 & \pm 0.06 \\
\hline & Dry & 7.43 & 7.49 & \pm 0.35 & 3.33 & 3.37 & \pm 0.13 & 2.16 & 2.18 & \pm 0.11 \\
\hline GZ10333-9-1-1-3 & Soaked & 7.54 & 7.60 & \pm 0.27 & 3.34 & 3.41 & \pm 0.18 & 2.22 & 2.24 & \pm 0.09 \\
\hline & Incubated & 8.01 & 8.07 & \pm 0.27 & 3.39 & 3.43 & \pm 0.18 & 2.27 & 2.29 & \pm 0.07 \\
\hline & Dry & 7.40 & 7.46 & \pm 0.28 & 3.37 & 3.41 & \pm 0.14 & 2.10 & 2.12 & \pm 0.07 \\
\hline $\begin{array}{c}G \angle 10332-19-2-L^{-} \\
2\end{array}$ & Soaked & 7.47 & 7.53 & \pm 0.28 & 3.40 & 3.44 & \pm 0.19 & 2.18 & 2.20 & \pm 0.11 \\
\hline & Incubated & 7.52 & 7.58 & \pm 0.27 & 3.44 & 3.48 & \pm 0.15 & 2.24 & 2.26 & \pm 0.10 \\
\hline & Dry & 7.20 & 7.26 & \pm 0.28 & 3.35 & 3.39 & \pm 0.17 & 2.14 & 2.16 & \pm 0.11 \\
\hline $\begin{array}{c}G \angle 10305-24-1-2- \\
3\end{array}$ & Soaked & 7.41 & 7.47 & \pm 0.28 & 3.36 & 3.45 & \pm 0.18 & 2.28 & 2.30 & \pm 0.08 \\
\hline & Incubated & 7.53 & 7.59 & \pm 0.29 & 3.46 & 3.50 & \pm 0.15 & 2.34 & 2.36 & \pm 0.12 \\
\hline & Dry & 7.84 & 7.90 & \pm 0.25 & 3.12 & 3.16 & \pm 0.13 & 2.08 & 2.10 & \pm 0.08 \\
\hline GZ10154-3-1-1-1 & Soaked & 7.89 & 7.95 & \pm 0.33 & 3.13 & 3.21 & \pm 0.12 & 2.25 & 2.27 & \pm 0.10 \\
\hline & Incubated & 7.96 & 8.02 & \pm 0.26 & 3.19 & 3.23 & \pm 0.18 & 2.28 & 2.30 & \pm 0.09 \\
\hline & Dry & 7.37 & 7.43 & \pm 0.27 & 3.31 & 3.35 & \pm 0.16 & 2.13 & 2.15 & \pm 0.06 \\
\hline $\begin{array}{c}G \angle 10305-2-1-3- \\
1-1\end{array}$ & Soaked & 7.41 & 7.47 & \pm 0.27 & 3.36 & 3.45 & \pm 0.18 & 2.31 & 2.33 & \pm 0.07 \\
\hline & Incubated & 7.44 & 7.50 & \pm 0.25 & 3.45 & 3.49 & \pm 0.1 & 2.35 & 2.37 & \pm 0.11 \\
\hline & Dry & 7.24 & 7.30 & \pm 0.20 & 3.21 & 3.25 & \pm 0.11 & 2.12 & 2.14 & \pm 0.09 \\
\hline GZ10264-9-2-1-2 & Soaked & 7.95 & 8.01 & \pm 0.23 & 2.88 & 3.92 & \pm 0.12 & 2.13 & 2.15 & \pm 0.10 \\
\hline & Incubated & 8.14 & 8.20 & \pm 0.25 & 3.19 & 3.98 & \pm 0.13 & 2.26 & 2.28 & \pm 0.11 \\
\hline
\end{tabular}




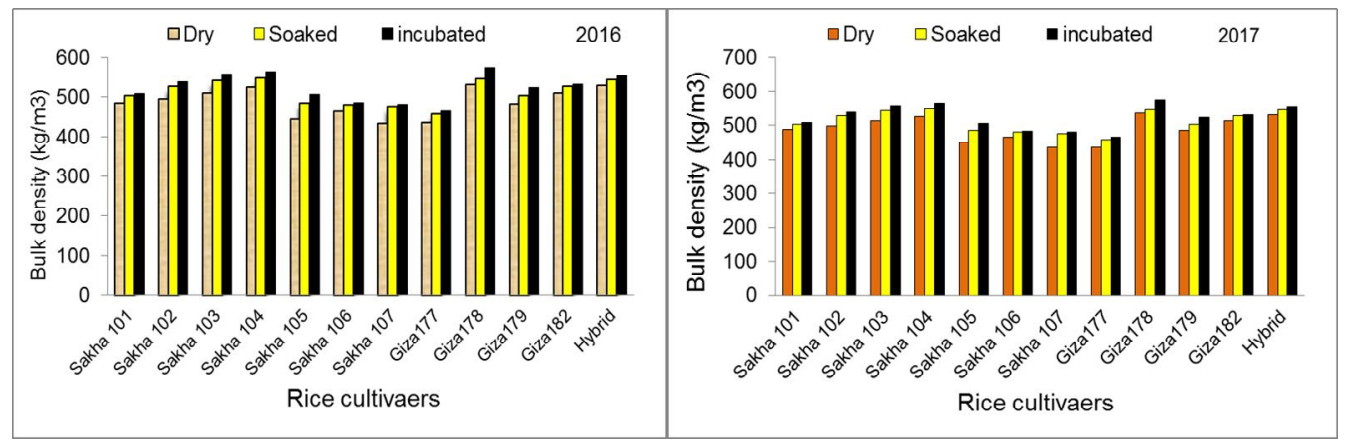

Fig. 2. Effect of grains moisture content on bulk density of rice grains for rice cultivars in 2016 and 2017 seasons.

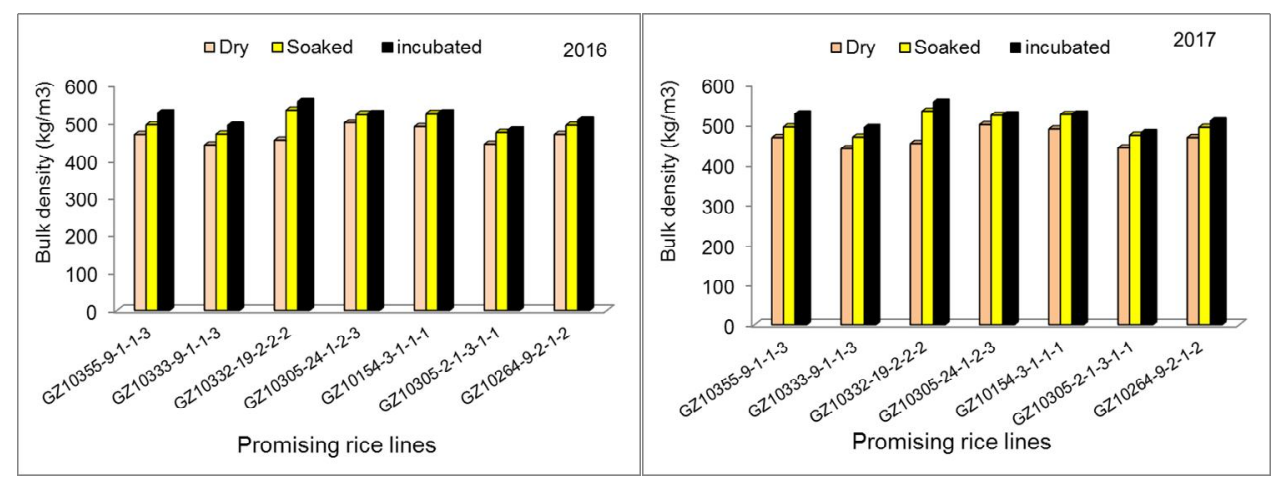

Fig. 3. Effect of grains moisture content on bulk density of rice grains for promising rice lines in 2016 and 2017 seasons.

\section{Effect of grains moisture content on true density for all rice genotypes:}

The effect of grains moisture content on true density of rice grains of all rice genotypes are shown in Figs (4 and 5). In general the true density increased with the increasing of grain moisture content for all rice genotypes. For old rice varieties, Sakha 104 recorded the highest values of true density, which increased from 1192.94 to 1372.60 to $1407.27 \mathrm{~kg} / \mathrm{m}^{3}$ with increasing of grain moisture content from 14.38 to 25.67 to $28.98 \%$ for season 2016 and which increasing from 1192.94 to 1367.21 to $1402.38 \mathrm{~kg} / \mathrm{m}^{3}$ with increasing of grain moisture content from 14.81 to 26.02 to 29.37 $\%$ for season 2017 respectively. Meanwhile, Rice variety (Giza 177) recorded the lowest values of true density, which increased from 1074.44 to 1208.97 to 1224.63 $\mathrm{kg} / \mathrm{m}^{3}$ with increasing from 14.38 to 25.67 to $28.98 \%$ for season 2015 and which increasing from 1068.96 to 1203.58 to $1219.74 \mathrm{~kg} / \mathrm{m}^{3}$ with increasing of grain moisture content from 14.81 to 26.02 to $29.37 \%$, respectively.

Also, rice genotype (GZ 10355-9-1-1-3) recorded the highest values of true density, which increased from 1165.1 to 1267.3 to $1367.2 \mathrm{~kg} / \mathrm{m}^{3}$ with increasing of grain moisture content from 14.38 to 25.67 to $28.98 \%$ for season 2016 and which increasing from 1160.5 to 1263.0 to $1361.5 \mathrm{~kg} / \mathrm{m}^{3}$ for season 2017 , with increasing of grain moisture content from 14.81 to 26.02 to $29.37 \%$, respectively. Meanwhile, rice 
genotype (GZ10333-9-1-1-3) recorded the lowest values of true density, which increased from 1075.9 to 1201.6 to $1223.1 \mathrm{~kg} / \mathrm{m}^{3}$ with increasing of grain moisture content from 14.38 to 25.67 to $28.98 \%$ for season 2016 , and which increasing from 1071.4 to 1197.3 to $1217.4 \mathrm{~kg} / \mathrm{m}^{3}$ for season 2017 respectively for new rice genotypes respectively.

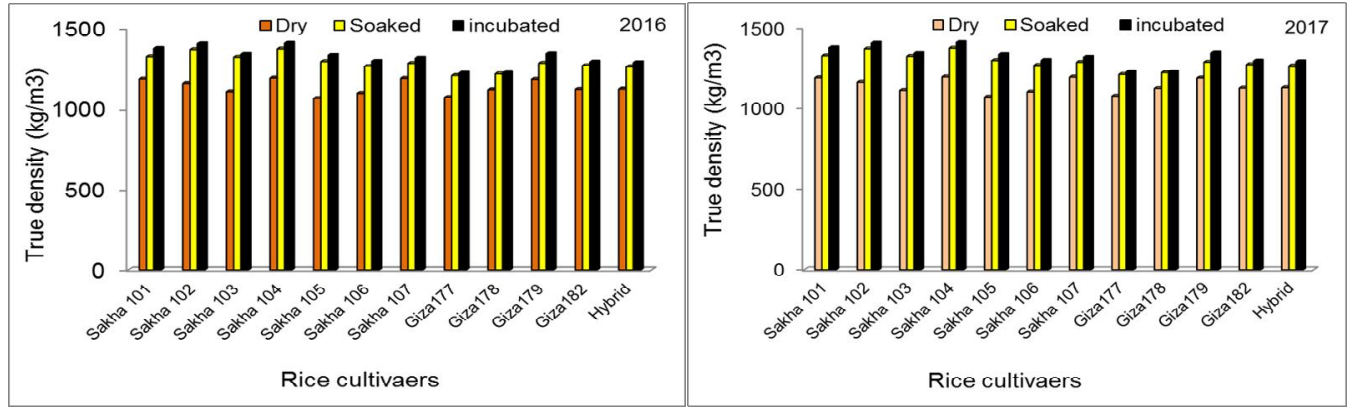

Fig. 4. Effect of grains moisture content on true density of rice grains for rice cultivars in 2016 and 2017 seasons.

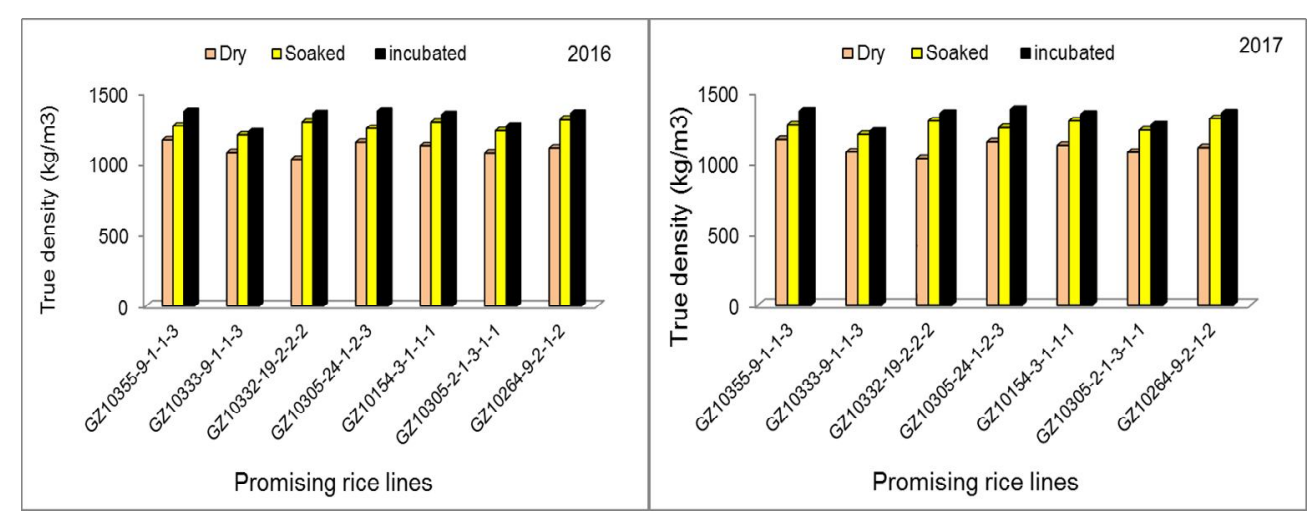

Fig. 5. Effect of grains moisture content on true density for promising rice in 2016 and 2017 seasons.

From the above results, it can be mentioned that increasing the period of soaking seeds increased the average true density for all rice genotypes within the time period used in the study. 
Table 3. The average values of 1000 mass, arithmetic and geometric mean diameters, sphericity, surface area and shape index for all cultivated rice.

\begin{tabular}{|c|c|c|c|c|c|c|c|c|c|c|c|c|c|}
\hline \multirow[t]{2}{*}{ Variety } & \multirow{2}{*}{$\begin{array}{l}\text { Moisture } \\
\text { content }\end{array}$} & \multicolumn{2}{|c|}{$\begin{array}{l}\text { Geometric mean } \\
\text { diameter }(\mathrm{mm})\end{array}$} & \multicolumn{2}{|c|}{$\begin{array}{l}\text { Arithmetic mean } \\
\text { diameter (mm) }\end{array}$} & \multicolumn{2}{|c|}{1000 mass $(\mathrm{g})$} & \multicolumn{2}{|c|}{ Degree of sphericity } & \multicolumn{2}{|c|}{$\begin{array}{l}\text { surface area } \\
\left(\mathrm{mm}^{2}\right)\end{array}$} & \multicolumn{2}{|c|}{ Shape index } \\
\hline & & 2016 & 2017 & 2016 & 2017 & 2016 & 2017 & 2016 & 2017 & 2016 & 2017 & 2016 & 2017 \\
\hline \multirow{3}{*}{ Sakha 101} & Dry & 3.64 & 3.85 & 4.37 & 4.56 & 28.89 & 29.02 & 0.477 & 0.510 & 43.89 & 43.94 & 3.04 & 3.07 \\
\hline & Soaked & 380 & 4.01 & 4.48 & 4.67 & 34.91 & 35.04 & 0.495 & 0.528 & 47.28 & 47.33 & 2.87 & 2.9 \\
\hline & incubated & 3.91 & 4.12 & 4.79 & 4.98 & 37.13 & 37.26 & 0.526 & 0.559 & 48.00 & 48.05 & 2.76 & 2.79 \\
\hline \multirow{3}{*}{ Sakha 102} & Dry & 3.36 & 3.57 & 4.19 & 4.38 & 27.07 & 27.2 & 0.481 & 0.514 & 44.35 & 44.40 & 2.98 & 3.01 \\
\hline & Soaked & 3.53 & 3.74 & 4.49 & 4.68 & 36.54 & 36.67 & 0.503 & 0.536 & 47.47 & 47.52 & 2.80 & 2.83 \\
\hline & incubated & 3.98 & 4.19 & 4.89 & 5.08 & 37.45 & 37.58 & 0.504 & 0.537 & 48.50 & 48.55 & 2.79 & 2.82 \\
\hline \multirow{3}{*}{ Sakha 103} & Dry & 3.65 & 3.86 & 4.18 & 4.37 & 24.05 & 24.18 & 0.503 & 0.536 & 41.91 & 41.96 & 2.80 & 2.83 \\
\hline & Soaked & 3.76 & 3.97 & 4.22 & 4.41 & 31.30 & 31.43 & 0.528 & 0.561 & 44.39 & 44.44 & 2.61 & 2.64 \\
\hline & incubated & 3.86 & 4.07 & 4.75 & 4.94 & 33.07 & 33.2 & 0.528 & 0.561 & 45.00 & 45.05 & 2.51 & 2.54 \\
\hline \multirow{3}{*}{ Sakha 104} & Dry & 3.81 & 4.02 & 4.34 & 4.53 & 27.4 & 27.53 & 0.489 & 0.522 & 42.42 & 42.47 & 3.03 & 3.06 \\
\hline & Soaked & 3.96 & 4.17 & 4.55 & 4.74 & 33.40 & 33.53 & 0.497 & 0.530 & 45.29 & 45.34 & 2.85 & 2.88 \\
\hline & incubated & 4.08 & 4.29 & 4.48 & 4.67 & 36.12 & 36.25 & 0.528 & 0.561 & 49.17 & 49.22 & 3.81 & 3.84 \\
\hline \multirow{3}{*}{ Sakha 105} & Dry & 3.77 & 3.98 & 4.44 & 4.63 & 25.29 & 25.42 & 0.481 & 0.514 & 44.73 & 44.78 & 3.11 & 3.14 \\
\hline & Soaked & 3.85 & 4.06 & 4.45 & 4.64 & 34.55 & 34.68 & 0.489 & 0.522 & 45.58 & 45.63 & 2.92 & 2.95 \\
\hline & incubated & 3.89 & 4.10 & 4.69 & 4.88 & 35.13 & 35.26 & 0.489 & 0.522 & 46.58 & 46.63 & 2.84 & 2.87 \\
\hline \multirow{3}{*}{ Sakha 106} & Dry & 3.73 & 3.94 & 4.27 & 4.46 & 26.04 & 26.17 & 0.502 & 0.535 & 43.68 & 43.73 & 2.89 & 2.92 \\
\hline & Soaked & 3.82 & 4.03 & 4.34 & 4.53 & 33.33 & 33.46 & 0.512 & 0.545 & 44.91 & 44.96 & 2.73 & 2.76 \\
\hline & incubated & 3.94 & 4.15 & 483 & 4.83 & 35.03 & 35.16 & 0.558 & 0.591 & 45.67 & 45.72 & 2.71 & 2.74 \\
\hline \multirow{3}{*}{ Sakha 107} & Dry & 3.85 & 4.06 & 4.24 & 4.43 & 28.06 & 28.19 & 0.686 & 0.719 & 39.75 & 39.80 & 2.79 & 2.82 \\
\hline & Soaked & 3.89 & 4.10 & 4.41 & 4.60 & 34.69 & 34.82 & 0.516 & 0.549 & 47.12 & 47.17 & 2.69 & 2.72 \\
\hline & incubated & 3.94 & 4.15 & 4.69 & 4.88 & 36.00 & 36.13 & 0.540 & 0.573 & 47.86 & 47.91 & 2.65 & 2.68 \\
\hline \multirow{3}{*}{ Giza177 } & Dry & 3.74 & 3.95 & 4.29 & 4.48 & 25.79 & 25.92 & 0.500 & 0.533 & 43.97 & 44.02 & 2.83 & 2.86 \\
\hline & Soaked & 3.82 & 4.03 & 4.33 & 4.52 & 31.43 & 31.56 & 0.514 & 0.547 & 45.27 & 45.32 & 2.79 & 2.82 \\
\hline & incubated & 3.95 & 4.16 & 4.83 & 5.02 & 33.47 & 33.6 & 0561 & 0.594 & 45.94 & 45.99 & 2.73 & 2.76 \\
\hline \multirow{3}{*}{ Giza178 } & Dry & 3.45 & 3.66 & 4.05 & 4.24 & 19.83 & 19.96 & 0.496 & 0.529 & 37.32 & 37.37 & 3.15 & 3.18 \\
\hline & Soaked & 3.57 & 3.78 & 4.12 & 4.31 & 26.13 & 26.26 & 0.487 & 0.520 & 39.91 & 39.96 & 2.94 & 2.97 \\
\hline & incubated & 3.89 & 4.10 & 4.51 & 4.70 & 27.25 & 27.38 & 0.519 & 0.552 & 40.76 & 40.81 & 2.91 & 2.94 \\
\hline \multirow{3}{*}{ Giza179 } & Dry & 3.74 & 3.95 & 4.39 & 4.58 & 26.88 & 27.01 & 0.462 & 0.495 & 43.85 & 43.90 & 3.22 & 3.25 \\
\hline & Soaked & 3.82 & 4.03 & 4.43 & 4.62 & 33.86 & 33.99 & 0.481 & 0.514 & 45.22 & 45.27 & 3.01 & 3.04 \\
\hline & incubated & 3.85 & 4.06 & 4.54 & 4.73 & 35.83 & 35.96 & 0.475 & 0.508 & 45.71 & 45.76 & 3.05 & 3.08 \\
\hline \multirow{3}{*}{ Giza182 } & Dry & 3.59 & 3.80 & 4.64 & 4.83 & 24.00 & 24.13 & 0.381 & 0.414 & 40.51 & 40.56 & 4.25 & 4.28 \\
\hline & Soaked & 3.73 & 3.94 & 4.72 & 4.91 & 31.33 & 31.46 & 0.395 & 0.428 & 43.69 & 43.74 & 4.03 & 4.06 \\
\hline & incubated & 3.79 & 4.00 & 4.89 & 5.08 & 32.27 & 32.4 & 0.344 & 0.377 & 43.89 & 43.94 & 3.99 & 4.02 \\
\hline \multirow{3}{*}{$\begin{array}{l}\text { Hybrid } \\
\text { ricel }\end{array}$} & Dry & 3.57 & 3.78 & 4.31 & 4.50 & 22.91 & 23.04 & 0.443 & 0.476 & 40.19 & 40.24 & 3.39 & 3.42 \\
\hline & Soaked & 3.67 & 3.88 & 4.36 & 4.55 & 29.88 & 30.01 & 0.456 & 0.489 & 42.32 & 42.37 & 3.25 & 3.28 \\
\hline & incubated & 3.86 & 4.07 & 4.72 & 4.91 & 30.51 & 30.64 & 0.458 & 0.491 & 42.66 & 42.71 & 3.22 & 3.25 \\
\hline
\end{tabular}




\section{Effect of moisture content on $\mathbf{1 0 0 0}$ mass weight, arithmetic and geometric} mean diameters, sphericity, surface area and shape index for all cultivated rice:

Tables ( 3 and 4) shown the effect of moisture content on average values of 1000 mass weight, arithmetic and geometric mean diameters, sphericity, surface area and shape index for all rice_varieties for two studied seasons 2016 and 2017. It were noted that the 1000 mass, arithmetic and geometric mean diameters, sphericity, surface area and shape index gradually increased with additional grains moisture content increased for all cultivated rice. It can be recorded that the increase in 1000 mass, arithmetic and geometric mean diameters, sphericity, surface area and shape index in the first period from dry to soaked seeds are a larger period than for the second period of the soaked to the incubated seeds and this is normal because the seeds will be saturated with water.

Table 4. The average values of 1000 mass, arithmetic and geometric mean diameters, sphericity, surface area and shape index for all new promising rice lines.

\begin{tabular}{|c|c|c|c|c|c|c|c|c|c|c|c|c|c|}
\hline \multirow[t]{2}{*}{ Variety } & \multirow{2}{*}{$\begin{array}{l}\text { Moisture } \\
\text { content }\end{array}$} & \multicolumn{2}{|c|}{$\begin{array}{l}\text { Geometric mean } \\
\text { diameter (mm) }\end{array}$} & \multicolumn{2}{|c|}{$\begin{array}{l}\text { Arithmetic mean } \\
\text { diameter (mm) }\end{array}$} & \multicolumn{2}{|c|}{1000 mass $(\mathrm{g})$} & \multicolumn{2}{|c|}{$\begin{array}{l}\text { Degree of } \\
\text { sphericity }\end{array}$} & \multicolumn{2}{|c|}{$\begin{array}{l}\text { surface area } \\
\qquad\left(\mathrm{mm}^{2}\right)\end{array}$} & \multicolumn{2}{|c|}{ Shape index } \\
\hline & & 2016 & 2017 & 2016 & 2017 & 2016 & 2017 & 2016 & 2017 & 2016 & 2017 & 2016 & 2017 \\
\hline \multirow{3}{*}{ GZ10355-9-1-1-3 } & Dry & 3.78 & 3.99 & 4.35 & 4.54 & 24.75 & 24.88 & 0.386 & 0.419 & 44.94 & 44.99 & 2.96 & 2.99 \\
\hline & Soaked & 3.92 & 4.13 & 4.54 & 4.73 & 32.53 & 32.66 & 0.489 & 0.522 & 48.28 & 48.33 & 2.93 & 2.96 \\
\hline & incubated & 3.95 & 4.16 & 4.91 & 5.10 & 35.58 & 35.71 & 0.501 & 0.534 & 49.03 & 49.08 & 2.82 & 2.85 \\
\hline \multirow{3}{*}{ GZ10333-9-1-1-3 } & Dry & 3.81 & 4.02 & 4.21 & 4.40 & 27.57 & 27.70 & 0.485 & 0.518 & 45.91 & 45.96 & 2.96 & 2.99 \\
\hline & Soaked & 3.82 & 4.03 & 4.37 & 4.56 & 30.89 & 31.02 & 0.507 & 0.540 & 46.21 & 46.26 & 2.77 & 2.80 \\
\hline & incubated & 3.86 & 4.07 & 4.82 & 5.01 & 33.70 & 33.83 & 0.517 & 0.550 & 47.37 & 47.42 & 2.69 & 2.72 \\
\hline \multirow{3}{*}{ GZ10332-19-2-2-2 } & Dry & 3.74 & 3.95 & 4.29 & 4.48 & 23.29 & 23.42 & 0.505 & 0.538 & 43.96 & 44.01 & 2.82 & 2.85 \\
\hline & Soaked & 3.82 & 4.03 & 4.36 & 4.55 & 31.53 & 31.66 & 0.508 & 0.541 & 45.76 & 45.81 & 2.76 & 2.79 \\
\hline & incubated & 3.88 & 4.09 & 4.92 & 5.11 & 32.90 & 33.03 & 0.516 & 0.549 & 46.73 & 46.78 & 2.69 & 2.72 \\
\hline \multirow{3}{*}{ GZ10305-24-1-2-3 } & Dry & 3.78 & 3.99 & 4.34 & 4.53 & 25.28 & 25.41 & 0.503 & 0.536 & 44.89 & 44.94 & 2.81 & 2.84 \\
\hline & Soaked & 3.84 & 4.05 & 4.35 & 4.54 & 31.23 & 31.36 & 0.519 & 0.552 & 46.42 & 46.47 & 2.67 & 2.70 \\
\hline & incubated & 3.88 & 4.09 & 4.66 & 4.85 & 36.31 & 36.44 & 0.524 & 0.557 & 47.15 & 47.20 & 2.63 & 2.66 \\
\hline \multirow{3}{*}{ GZ10154-3-1-1-1 } & Dry & 3.72 & 3.93 & 4.39 & 4.58 & 25.85 & 25.98 & 0.468 & 0.501 & 43.55 & 43.60 & 3.12 & 3.15 \\
\hline & Soaked & 3.81 & 4.02 & 4.42 & 4.61 & 31.97 & 32.1 & 0.481 & 0.514 & 45.66 & 45.71 & 2.98 & 3.01 \\
\hline & incubated & 3.85 & 4.06 & 4.73 & 4.92 & 35.42 & 35.55 & 0.491 & 0.524 & 46.56 & 46.61 & 2.91 & 2.94 \\
\hline \multirow{3}{*}{ GZ10305-2-1-3-1-1 } & Dry & 2.59 & 2.80 & 4.29 & 4.48 & 24.33 & 24.46 & 0.502 & 0.535 & 46.26 & 46.31 & 2.81 & 2.84 \\
\hline & Soaked & 3.76 & 3.97 & 4.36 & 4.55 & 31.62 & 31.75 & 0.521 & 0.554 & 46.73 & 46.78 & 2.66 & 2.69 \\
\hline & incubated & 3.87 & 4.08 & 4.56 & 4.75 & 35.49 & 35.62 & 0.536 & 0.569 & 47.06 & 47.11 & 2.62 & 2.65 \\
\hline \multirow{3}{*}{ GZ10264-9-2-1-2 } & Dry & 3.50 & 3.71 & 4.18 & 4.37 & 26.21 & 26.34 & 0.467 & 0.500 & 43.34 & 43.39 & 3.13 & 3.16 \\
\hline & Soaked & 3.54 & 3.75 & 4.48 & 4.67 & 35.03 & 35.16 & 0.489 & 0.522 & 44.34 & 44.39 & 2.92 & 2.95 \\
\hline & incubated & 3.85 & 4.06 & 4.68 & 4.87 & 36.12 & 36.25 & 0.525 & 0.558 & 46.67 & 46.72 & 2.86 & 2.89 \\
\hline
\end{tabular}

From the above results, it can be recorded that the increase in seeds soaking period resulted in increase the 1000 mass weight, arithmetic and geometric mean 
diameters, sphericity, surface area and shape index of rice grain within the time period used in the study. Because of these findings have an important role in the field of design, development and manufacturing of precision direct seeding machine as well as conduct in damage and distribution uniformity of rice grains after soaking and incubating.

From previous results, it was clear that all values of shape index for all rice genotypes higher than 1.5 , this intend that all rice treatment take oval shape. This contributed us to fabricate precision direct seeding machine seed holes as a cylindrical shape and to disqualify spherical form.

\section{In general the results could be summarized as flow:-}

- The mean values of moisture content for all rice genotypes in 2016 and 2017 seasons were (14.38, 25.67 and 28.98\%) and 14.81, 26.02 and 29.37\%) respectively for dry, soaked for one day and incubated for two days seed respectively.

- The grain dimensions gradually increased with additional moisture content increased for all rice grains genotypes. From previous results, it was clear that the shortest dimensions of rice grains were at dry seeds $(1.92 \pm 0.08 \mathrm{~mm})$ as well as using the database to design of hole diameter for seed plate less than $1.92 \mathrm{~mm}$ for precision machine. Therefore the pertinent hole diameter for all rice grains genotypes was $1.5 \mathrm{~mm}$.

- It can be recorded that increasing the period of soaking seeds increased the average bulk and true density for all rice genotypes within the time period used in the study.

- It can be recorded that increasing the period of soaking seeds increased the 1000 mass, arithmetic and geometric mean diameters, sphericity, surface area and shape index of rice grain within the time period used in the study.

\section{CONCLUSION}

- The aimed of this study to investigate some engineering properties of 19 rice genotypes (12 rice cultivars and 7 promising lines) cultivated in Egypt, in order to setup database for rice genotypes as well as its use to design Precision agriculture machines at different seed moisture contents for various manner of direct seeded rice approaches.

- Laboratory experiment was carried out during summer season of 2017 at (Rice Research Department - Field Crops Research Institute - Kafr El-Sheikh Governorate collaborated with Tractor Farm Machinery Test and Research Station -Alex). The rice grain properties of (dry, soaked and incubated) were tested. 


\section{REFERENCES}

1. Abo-Habaga, M. M.; A. E. Abo-Elmagd; M. A. El-Sadany; M. I. Egela and M.I. ElMeadawy. 2014. Development of a suitable planter for hybrid rice crop. J. Agric. Sci. and Agric. Eng., Mansoura Univ., 5 (5): 721 - 737.

2. Abo-Youssef, M. I.; S. Gh. Sorour, M. Z. Abdelkrem, and M. A. Tawfik. 2011. The effect of sowing date on the productivity of some rice varieties. J. Agric. Res. Kafer El-Sheikh Univ., 37 (2): 317-330.

3. Bashar, Z. U., A. Wayayok and A. M. S. Mohd. 2014. Determination of some physical properties of common Malaysian rice MR219 seeds. AJCS 8(3):332-337 ISSN:1835-2707.

4. Ibrahim, M. M.; H. N. Abd El-Mageed, and T. H. Abd-Alla. 2008. Evaluation the field performance of a developed planting machine sutable for soaked rice". Misr J. Ag. Eng., 25(3): 677-692

5. Ismail, Z. E. 1988. "Some of the phsio-mechanical properties for potato tubers". J. Agric. Sci. Mansoura Univ. 13 B (4): 2259 - 2270.

6. Matouk, A. M.; S. M. Radwan; M. M. El-Kholy and T. R. Ewies. 2004. Determination of grains density and porosity for some cereal crop. Misr J. Ag. Eng., 21(3): 623-641.

7. Mohsenin, N. N. 1986. Physical properties of plant and animal materials". Gordon and Breach Science Pub., N.Y.: 103-105.

8. Varnamkhasti, M. G.; H. Mobli; A. Jafari; A.R. Keyhani; M. Heidari Soltanabadi; S. Rafiee and K. Kheiralipour. 2008. Some physical properties of rough rice (Oryza Sativa L.) grain. Journal of Cereal Science 47: 496-501.

$$
\text { مراجع عربية }
$$

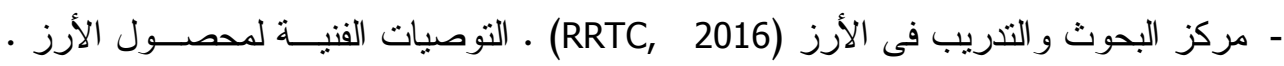
برنامج الأرز - مركز البحوث الزر اعية - وز ارة الزر اعة. 


\section{بعض الخواص الهندسية اللازمة لمنطلبات \\ الزراعة الاقيقة لأصناف الأرز المختلفة}

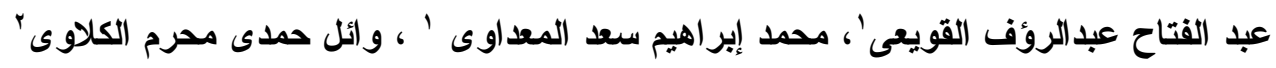

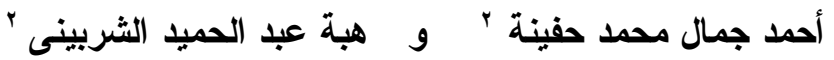

$$
\begin{aligned}
& \text { " معهز بحوث الهندسة الزراعية - وزارة الزراعة - الدقي - الجيزة }
\end{aligned}
$$

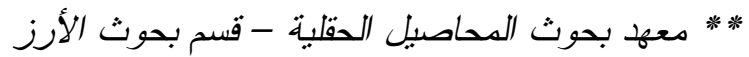

يعتبر محصول الأرز واحد من أهم محاصيل الحبوب في مصر والكثير من دول العالم، الماء

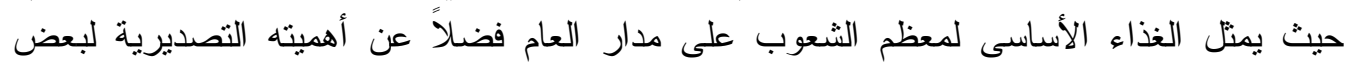
الدول. وفى مصر يعتمد عليه الكثير من المزارعين كمصدر دخل رئيسى حيث كانت المساحة

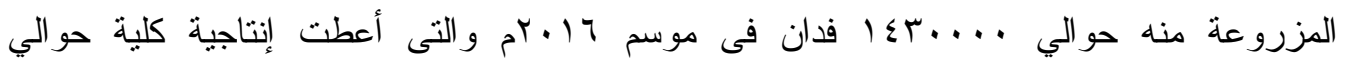
فـ ـ ... .

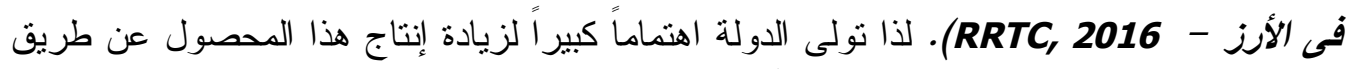

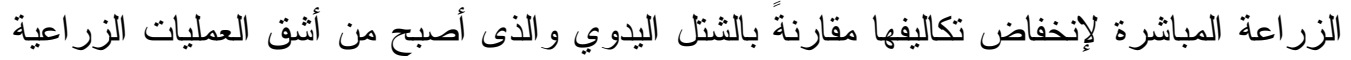

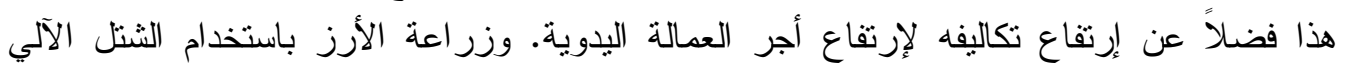

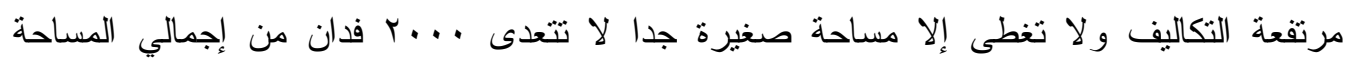

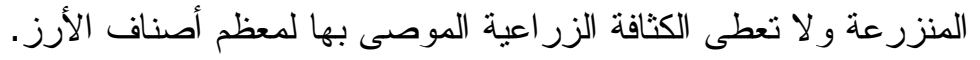
وتعتبر الزراعة الدقيقة من طرق الزر اعة الحديثة النى تقلل من تكاليف إنتاج المحاصيل

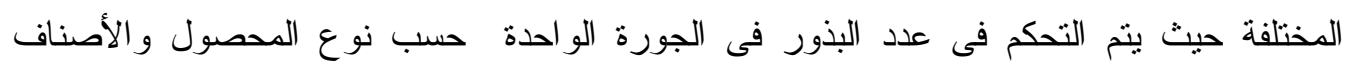

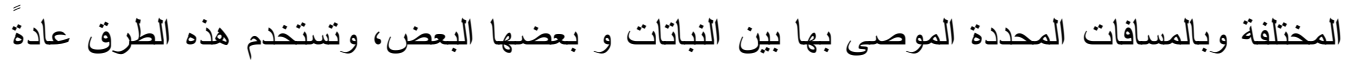

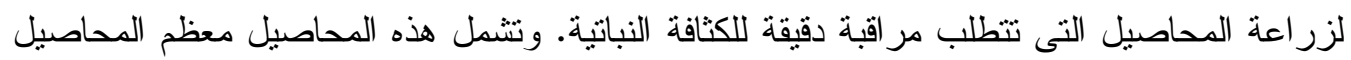

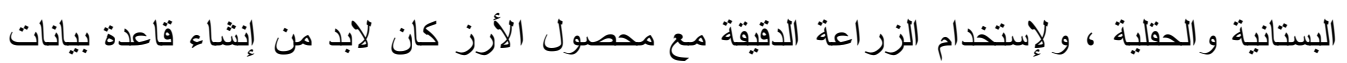

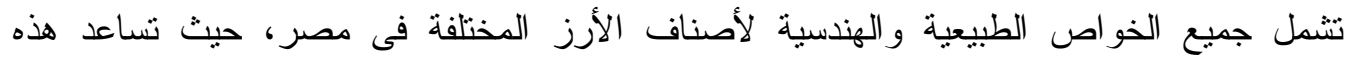

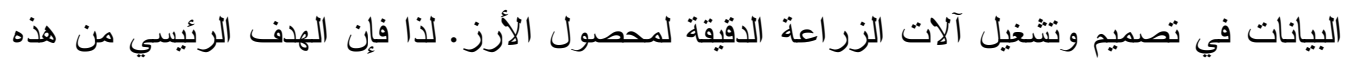

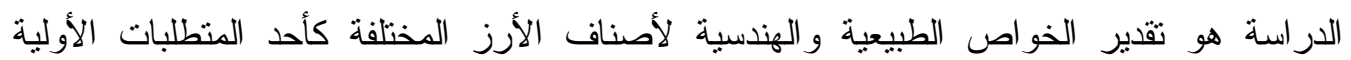

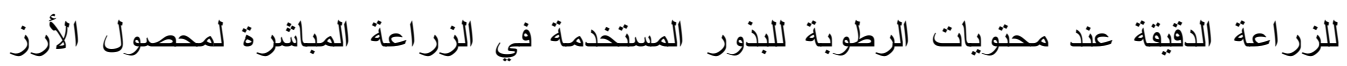

$$
\text { (جافة - منقو عة - مكمورة). }
$$

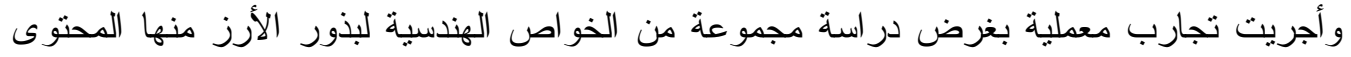

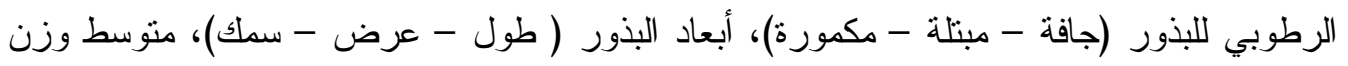

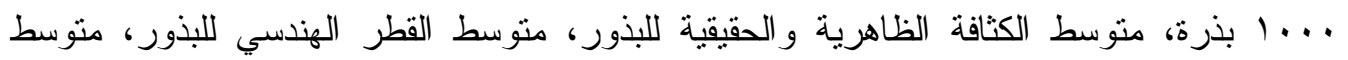

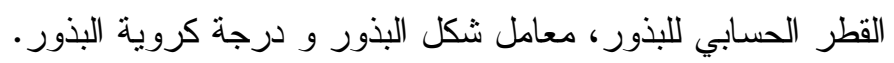

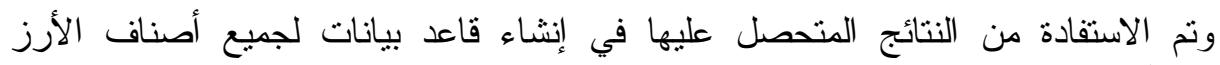

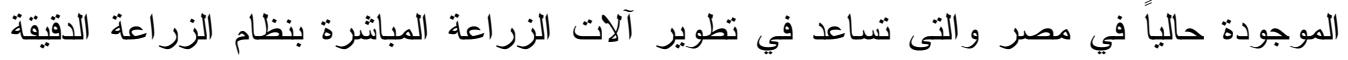
لتحديد العدد الامثل من الحبوب لوحدة المساحة طبقا للتوصيات الفنية لزر اعة أصناف الأرز المختلفة. 
1054

SOME ENGINEERING PROPERTIES REQUIRED TO PRECISION SEEDING OF DIFFERENT RICE GENOTYPES 